\title{
Pengaruh Terapi Progressive Muscle Relaxation (PMR) terhadap Depresi Pada Lansia di Panti Sosial Tresna Werdha (PSTW) Sabai Nan Aluih Sicincin
}

\author{
Rezky Pradessetia*, Rika Sabri, Dewi Eka Putri \\ Fakultas Keperawatan, Universitas Andalas \\ Limau Manis, Kec. Pauh, Kota Padang, Sumatera Barat, Indonesia, 25163 \\ *correspondence email: pradessetyarezky@gmail.com
}

\begin{abstract}
Abstrak. Masalah depresi masih sering terjadi di Indonesia. Sumatera Barat berada diposisi ketujuh dari 34 provinsi dengan masalah depresi terbanyak. Terdapat empat penanganan depresi pada lansia, yaitu pendekatan psikologis, medis, spiritual dan fisik. Terapi Progressive Muscle Relaxation (PMR) menjadikan tubuh rileks. perasaan tenang sehingga ketegangan berkurang. Dengan adanya perasaan rileks dan tenang individu akan lebih mudah untuk merasakan ketenangan pada pikiran dan perasaan. Tujuan penelitian ini untuk mengetahui pengaruh Terapi Progressive Muscle Relaxation (PMR) terhadap depresi pada lansia. Penelitian eksperimental dengan rancangan Quasi experimental pre and post test with control group. Teknik sampling adalah simple random sampling. Sampel berjumlah 40 lansia, yang dibagi menjadi dua kelompok, yaitu kelompok intervensi dan kelompok kontrol. Pengukuran skor depresi menggunakan kuesioner Geriatric Depression Scale (GDS) dengan jumlah pertanyaan sebanyak 15 butir. Analisa data menggunakan uji Uji Independent T Test. Hasil penelitian ini adalah terjadi penurunan skor depresi susudah diberikan perlakukan Terapi Progressive Muscle Relaxation (PMR) pada kelompok intervensi, dengan nilai $\mathrm{p}=0,000(\mathrm{p}<0,05)$. Hal ini menunjukkan bahwa ada perubahan skor depresi yang dialami oleh lansia setelah diberikan Terapi Progressive Muscle Relaxation (PMR). Terapi Progressive Muscle Relaxation (PMR) dapat diaplikasikan sebagai terapi nonfarmakologi di Panti Sosial Tresna Werdha (PSTW).
\end{abstract}

Kata kunci: Depresi; Lansia; Terapi Progressive Muscle Relaxation (PMR); Kuesioner Geriatric Depression Scale (GDS)

Abstract. The problem of depression is still common in Indonesia. West Sumatra is in seventh position out of 34 provinces with the most depression problems. There are four treatments for depression in the elderly, namely psychological, medical, spiritual and physical approaches. Progressive Muscle Relaxation (PMR) therapy makes the body relax. feeling calm so tension is reduced. With a feeling of relaxation and calm, individuals will find it easier to feel calm in their thoughts and feelings. Aim Knowing the effect of Progressive Muscle Relaxation (PMR) therapy on depression in the elderly. Experimental research with Quasi experimental design pre and post test with control group. The sampling technique is simple random sampling. The sample consisted of 40 elderly people, who were divided into two groups, namely the intervention group and the control group. Measurement of depression scores using the Geriatric Depression Scale (GDS) questionnaire with a total of 15 questions. Data analysis using Paired Sample T Test test. There was a decrease in depression scores after being treated with Progressive Muscle Relaxation $(P M R)$ therapy in the intervention group, with $p=0.000(p<0.05)$. This shows that there is a change in depression scores experienced by the elderly after being given Progressive Muscle Relaxation (PMR) Therapy. Therapy Progressive Muscle Relaxation (PMR) can be applied as a non-pharmacological therapy at the Panti Tresna Werdha (PSTW).

Keywords: Depression, Elderly; Therapy Progressive Muscle Relaxation (PMR); Panti Tresna Werdha (PSTW); Geriatric Depression Scale (GDS) Questionnaire

\section{PENDAHULUAN}

Lansia didunia meningkat menjadi 810 juta orang dan diproyeksikan akan terus meningkat jumlahnya bahkan mencapai 2 miliyar pada tahun 2050 (Badan Pusat Statistik, 2020). Indonesia merupakan termasuk kedalam kategori 5 negara dengan jumlah penduduk lansia terbanyak didunia. Pada tahun 2019, persentase lansia mencapai $9,60 \%$ atau sekitar 25,64 juta orang (Badan Pusat Statistik, 2019). Pada tahun 2020, persentase lansia mengalami peningkatan mencapai 9,92\% atau sekitar 26,82 juta orang (Badan Pusat Statistik, 2020).

Kelompok lansia merupakan kelompok yang paling rentan dan berisiko mengalami gangguan kesehatan, dikarenakan sudah mulai menurunnya fungsi fisiologis dan kognitif pada tubuh lansia. Kemunduran fungsi kognitif dapat berupa mudah lupa (forgetfulness) yaitu bentuk gangguan kognitif yang paling ringan, gangguan ini diperkirakan dikeluhkan oleh $39 \%$ lansia berusia 50-59 tahun, meningkat menjadi lebih dari $85 \%$ pada usia lebih dari 80 tahun (Wreksoatmodjo, 2014). Hasil penelitian Muzamil et.al (2014) menemukan bahwa terjadinya penurunan fungsi kognitif pada lansia sebanyak sembilan orang $(17,6 \%)$ dari total 51 orang responden lansia.

Akibat dari penurunan pada fungsi fisiologis dan kognitif lansia dapat megalami masalah pada kesehatan psikologis atau kesehatan jiwa. Gangguan psikologis yang sering dialami oleh lansia adalah gangguan depresi (WHO, 2013). Hasil Riset Kesehatan Dasar (Riskesdas) 
tahun 2018 diketahui bahwa prevalensi gangguan depresi pada penduduk Indonesia adalah $6,1 \%$ atau sekitar 706.689 dari jumlah penduduk Indonesia. Pada kelompok usia 65-74 tahun 8,0\% atau sekitar 37.491 dari jumlah penduduk lansia, dan pada usia 75 tahun keatas adalah $8,9 \%$ atau sekitar 15.941 dari jumlah penduduk. Sedangkan di Sumatera Barat sendiri prevalensi gangguan depresi mencapai 8,2 \% atau sekitar 13.683 dari jumlah penduduk yang ada di Sumatera Barat. Dampak depresi yang dapat terjadi pada lansia adalah terjadinya gangguan pada fungsi fisik, fungsi psikososial dan yang paling berbahaya adalah keinginan lansia untuk melakukan suicide (bunuh diri) (Widianingrum, 2017). Berdasarkan data WHO (2018) prevalensi kejadian bunuh diri hampir 800.000 setiap tahun, dan setiap 40 detik satu orang melakukan bunuh diri.

Tenaga kesehatan harus lebih tanggap dalam mengatasi masalah tersebut. Hasil penelitian Ratri (2016) menjelaskan bahwa ada 4 penanganan depresi pada lansia, yaitu pendekatan psikologis, pendekatan medis, pendekatan spiritual dan pendekatan fisik. Terapi yang dapat diberikan kepada lansia yang mengalami depresi adalah Cognitive Therapy, Thought Stopping, dan Progresive Muscle Relaxation (PMR).

Progressive Muscle Relaxation (PMR) merupakan salah satu metode relaksasi sederhana melalui dua proses yaitu menegangkan dan merelaksasikan otot tubuh. Terapi Progressive Muscle Relaxation (PMR) dapat mengatasi ketegangan otot akibat depresi yang dialami oleh lansia sehingga menyebabkan tubuh menjadi rileks dan fikiran menjadi tenang. Penelitian yang dilakukan Rahmah (2017) tentang penerapan terapi Progressive Muscle Relaxation (PMR) dalam mengatasi depresi pada lansia yang membagi kelompok intervensi dan kelompok kontrol didapatkan hasil bahwa terjadi penurunan tingkat depresi yang signifikan pada kelompok intervensi setelah diberikan terapi.

Survey awal yang dilakukan peneliti di Panti Sosial Tresna Werdha Sabai Nan Aluih Sicincin yang merupakan salah satu tempat untuk merawat lansia di Sumatera Barat, memiliki 14 wisma yang menampung sekitar 110 lansia, diantaranya 69 orang lansia laki-laki dan 41 orang lansia wanita. Berdasarkan survey awal yang telah dilakukan oleh peneliti bahwa di Panti Sosial Tresna Werdha (PSTW) masih banyaknya lansia yang memiliki gejala depresi. Didapatkan hasil bahwa lansia yang diwawancara mengatakan bahwa hidupnya merasa kosong, hampa dan merasa sepi dikarenakan sudah tidak memeliki keluarga dan jauh dari keluarga, merasa bosan, merasa sedih dan sering merasa ingin menangis, tidak puas dengan kehidupan nya sekarang dan merasa kecewa dengan apa yang dilakukannya. Serta lansia merasa tidak berdaya karna harus dibantu untuk memenuhi kebutuhan sehari-harinya seperti makan dan mandi.
Tujuan dari penelitian ini untuk mengetahui pengaruh terapi Progressive Muscle Relaxation (PMR) terhadap depresi pada lansia di Panti Sosial Tresna Werdha (PSTW) Sabai Nan Aluih Sicincin.

\section{METODE}

Penelitian ini adalah penelitian kuantitatif. Desain yang digunakan adalah Quasi experimental pre and post test with control group. Rancangan ini menggunakan kelompok intervensi dan kelompok kontrol. Penelitian ini dilakukan untuk melihat perubahan rata-rata skor depresi pada responden sebelum dan sesudah mendapatkan Terapi Progressive Muscle Relaxation (PMR).

Teknik pengambilan sampel menggunakan total sampling. Sampel pada penelitian ini berjumlah 40 sampel, setelah dilakukan scrinning awal terlebih dahulu untuk mendapatkan lansia yang memiliki gejala depresi. Selanjutnya sampel dibagi menjadi dua kelompok yaitu 20 responden pada kelompok intervensi dan 20 responden pada kelompok kontrol. Penelitian ini akan menggunakan uji paired $\mathrm{t}$-test karena akan menguji hasil dari dua pengukuran (pre test dan post test) untuk melihat perubahan signifikan yang terjadi dan melihat pengaruh dari terapi yang dilakukan.

Penelitian ini dilakukan di Panti Sosial Tresna Werdha (PSTW) Sabai Nan Aluih Sicincin. Penelitian dimulai pada bulan Juni 2021 hingga Juli 2021.

Alat pengumpulan data karakteristik responden berupa usia, jenis kelamin, status pernikahan dan lama tinggal dipanti serta rata-rata skor depresi diukur menggunakan kuesioner Geriatric Depression Scale $(G D S)$.

Peneliti melakukan Terapi Progressive Muscle Relaxation (PMR) kepada kelompok intervensi dengan melalui tiga sesi yaitu, pada sesi satu peneliti mengindentifikasi ketegangan otot-otot tubuh tertentu yang dirasakan, pada sesi dua peneliti melakukan pelaksanaan terapi Progressive Muscle Relaxation (PMR), dan pada sesi ketiga peneliti mengevaluasi kemampuan klien melakukan latihan relaksasi progresif gerakan pertama hingga keempatbelas yang meliputi dahi, mata, rahang, mulut, leher, tangan, telapak tangan, lrngan, bahu, punggung, dada, perut tungkai dan kaki. Terapi dilaksanakan sebanyak sekali dalam sehari dan dilaksanakan selama 7 hari. Pelaksanaan terapi selama 30-45 menit yang akan di didampingi setiap hari nya oleh peneliti.

\section{HASIL DAN PEMBAHASAN \\ Analisa Univariat \\ Karakteristik Responden}


Rezky Pradessetia, Rika Sabri dan Dewi Eka Putri, Pengaruh Terapi Progressive Muscle Relaxation (PMR) terhadap Depresi Pada Lansia di Panti Sosial Tresna Werdha (PSTW) Sabai Nan Aluih Sicincin

Tabel 1. Distribusi Data Karakteristik Lansia di Panti Sosial Tresna Werdha (PSTW) Sabai Nan Aluih Berdasarkan Usia, Jenis Kelamin, Status Pernikahan, dan Lama Tinggal di Panti pada Kelompok Intervensi dan Kelompok Kontrol

\begin{tabular}{|c|c|c|c|c|c|}
\hline \multirow{2}{*}{\multicolumn{2}{|c|}{ Karakteristik }} & \multicolumn{2}{|c|}{ Kelompok intervensi } & \multicolumn{2}{|c|}{ Kelompok kontrol } \\
\hline & & Frekuensi & Persentase & Frekuensi & Persentase \\
\hline \multirow{2}{*}{ Usia } & 60-74 tahun (elderly) & 11 & 55 & 16 & 80 \\
\hline & 75-90 tahun (old) & 9 & 45 & 4 & 20 \\
\hline \multirow{2}{*}{ Jenis kelamin } & Laki laki & 11 & 55 & 7 & 35 \\
\hline & Perempuan & 9 & 45 & 13 & 65 \\
\hline \multirow{2}{*}{ Status pernikahan } & Janda & 9 & 45 & 13 & 65 \\
\hline & Duda & 11 & 55 & 7 & 35 \\
\hline Lama tinggal di & $<5$ tahun & 15 & 75 & 17 & 85 \\
\hline Panti & $\geq 5$ tahun & 5 & 25 & 3 & 15 \\
\hline
\end{tabular}

Berdasarkan tabel 1 diatas dapat dilihat bahwa sampel pada kelompok intervensi lebih banyak lansia lansia elderly, yaitu terdapat 11 lansia yang memiliki usia dalam kelompok elderly. Pada jenis kelamin kelompok intervensi sedikit lebih banyak laki-laki (55\%). Semua lansia sudah tidak memiliki pasangan, terdapat 11 lansia duda dan 9 lansia janda. Berdasarkan lama tinggal di panti rata-rata berada di panti $<5$ tahun yaitu dengan jumlah lansia sebanyak 15 .

Sedangkan pada kelompok kontrol usia didominasi oleh kelompok lansia elderly yaitu sebanyak
16 lansia. Pada jenis kelamin lebih bayak lansia perempuan dengan jumlah 13. Lansia pada kelompok kontrol juga sudah tidak memiliki pasangan, terdapat 13 lansia janda dan 7 lansia duda. Rata-rata lansia berada di panti $<5$ tahun yaitu dengan jumlah lansia sebanyak 17 $(85 \%)$.

Rata-Rata Skor Depresi Sebelum dan Sesudah Pemberian Terapi Progresive Muscle Relaxation (PMR) pada Kelompok Intervensi dan Kelompok Kontrol

Tabel 2. Rata-Rata Skor Depresi Sebelum dan Sesudah Pemberian Terapi Progresive Muscle Relaxation (PMR) pada Kelompok Intervensi dan Kelompok Kontrol di Panti Sosial Tresna Werdha (PSTW) Sabai Nan Aluih Juni-Juli 2021 (n=40)

\begin{tabular}{cccccc}
\hline \multirow{2}{*}{ Variabel } & \multirow{2}{*}{ Pengukuran } & \multicolumn{2}{c}{ Kelompok Intervensi } & \multicolumn{2}{c}{ Kelompok Kontrol } \\
\cline { 3 - 5 } & & Rata-rata & SD & Rata-rata & SD \\
\hline \multirow{2}{*}{ Depresi } & Sebelum & 10,45 & 1,820 & 10,60 & 2,237 \\
& Sesudah & 6,10 & 1,373 & 11,15 & 1,872 \\
\hline
\end{tabular}

Berdasarkan tabel 2 diatas, dapat dilihat terjadi penurunan yang bermakna dari rata-rata skor sebelum dan susudah diberikan perlakukan Terapi Progresive Muscle Relaxation (PMR) pada kelompok intervensi didapatkan rata-rata sebelum dari 10,45 menjadi 6,10 dengan SD 1,820 menjadi 1,373. Sedangkan pada kelompok kontrol yang tidak diberikan Terapi Progresive Muscle Relaxation (PMR) terjadi sedikit

peningkatan rata-rata skor depresi yaitu dari 10,60 menjadi 11,15 dengan SD 2,237 menjadi 1,872.

\section{Analisa Bivariat}

Uji rata-rata skor depresi sebelum dan sesudah perlakukan pada kelompok intervensi dan kelompok kontrol

Tabel 3. Uji Rata-Rata Skor Depresi Sebelum dan Sesudah Pemberian Terapi Progresive Muscle Relaxation (PMR) pada Kelompok Intervensi dan Kelompok Kontrol di Panti Sosial Tresna Werdha (PSTW) Sabai Nan Aluih Juni-Juli 2021 (n=40)

\begin{tabular}{|c|c|c|c|c|c|c|c|c|c|}
\hline \multirow[b]{2}{*}{ Variabel } & \multirow[b]{2}{*}{ Pengukuran } & \multicolumn{4}{|c|}{ Kelompok Intervensi } & \multicolumn{4}{|c|}{ Kelompok Kontrol } \\
\hline & & Rata-rata & SD & $\mathrm{t}$ & $\begin{array}{c}p \\
\text { value }\end{array}$ & Rata-rata & SD & $\mathrm{t}$ & $\begin{array}{c}p \\
\text { value }\end{array}$ \\
\hline \multirow{3}{*}{ Depresi } & Sebelum & 10,45 & 1,820 & \multirow{3}{*}{9,692} & \multirow{3}{*}{0,000} & 10,60 & 2,237 & \multirow{3}{*}{$-3,584$} & \multirow{3}{*}{0,002} \\
\hline & Sesudah & 6,10 & 1,373 & & & 11,15 & 1,872 & & \\
\hline & Selisih & 4,35 & 0,447 & & & $-0,55$ & 0,365 & & \\
\hline
\end{tabular}

Berdasarkan tabel 3 diatas, dapat dilihat terjadi penurunan yang bermakna dari rata-rata skor sebelum dan susudah diberikan perlakukan $(\mathrm{p}<0,05)$ Terapi Progresive Muscle Relaxation (PMR) pada kelompok intervensi yaitu dari 10,45 menjadi 6,10 sehingga terjadi penurunan skor sebesar 4,35. Sedangkan pada kelompok kontrol tanpa diberikan Terapi Progresive Muscle
Relaxation (PMR) terjadi sedikit peningkatan nilai ratarata depresi yaitu dari 10,60 menjadi 11,15 sehingga terjadi peningkatan skor sebesar 0,55.

Pengaruh pemberian terapi Progressive Muscle Relaxation (PMR) terhadap skor depresi lansia pada kelompok intervensi dan kelompok kontrol 
Rezky Pradessetia, Rika Sabri dan Dewi Eka Putri, Pengaruh Terapi Progressive Muscle Relaxation (PMR) terhadap Depresi Pada Lansia di Panti Sosial Tresna Werdha (PSTW) Sabai Nan Aluih Sicincin

Tabel 4. Pengaruh Terapi Progressive Muscle Relaxation (PMR) Terhadap Skor Depresi Lansia pada Kelompok Intervensi dan Kelompok Kontrol di Panti Sosial Tresna Werdha (PSTW) Sabai Nan Aluih Juni-Juli 2021 (n=40)

\begin{tabular}{ccccccc}
\hline Variable & Kelompok & $\mathrm{n}$ & Rata-rata & SD & $\mathrm{t}$ & p value \\
\hline \multirow{2}{*}{ Depresi } & Intervensi & 20 & 4,35 & 0,447 & \multirow{2}{*}{13,276} & \multirow{2}{*}{0,000} \\
& Kontrol & 20 & $-0,55$ & 0,365 & \\
\hline
\end{tabular}

Pada tabel 4 diatas menunjukkan bahwa adanya pengaruh Terapi Progressive Muscle Relaxation (PMR) terhadap skor depresi pada lansia, yaitu dibuktikan dengan nilai $(\mathrm{p}<0,05)$.

\section{Pembahasan}

\section{Rata-Rata Skor Depresi Sebelum dan Sesudah} Pemberian Terapi Progressive Muscle Relaxation (PMR) pada Kelompok Intervensi

Berdasarkan hasil uji yang dilakukan didapatkan hasil rata-rata skor depresi pada kelompok intervensi sebelum pemberian terapi Progressive Muscle Relaxation (PMR) adalah 10,45. Setelah diberikan terapi Progressive Muscle Relaxation (PMR) rata-rata skor depresi mengalami penurunan yang signifikan menjadi 6,10 .

Perubahan rata-rata skor depresi pada lansia tersebut didukung oleh beberapa faktor seperti usia lansia pada kelompok intervensi yang didominasi oleh kelompok lansia elderly, dengan usia maksimal usia lansia pada kelompok intervensi adalah 84 tahun dan usia minimal 64 tahun dengan demikian lansia masih mampu dengan lancar mengikuti proses pelaksanaan terapi Progressive Muscle Relaxation (PMR) dengan baik dan penuh semangat. Terapi Progressive Muscle Relaxation (PMR) menimbulkan perasaan tenang sehingga ketegangan berkurang. Dengan adanya perasaan rileks dan tenang individu akan lebih mudah untuk merasakan ketenangan baik itu pada pikiran nya ataupun dalam persaan individu tersebut (Diahputri, 2017).

Penelitian ini membuktikan penelitian yang dilakukan oleh Rahmah (2017) tentang Keefktifan Relaksasi Otot Progresif untuk Menurunkan Tingkat Depresi Lansia di Panti Jompo Tresna Werdha Mulia Dharma. Penelitian dilakukan pada 28 responden, terdapat 14 responden kelompok intervensi dan 14 responden kelompok kontrol. Didapatkan hasil pada penelitian ini bahwa Relaksasi otot progresif efektif dalam menurunkan tingkat depresi lansia di Panti Jompo Tresna Werdha Mulia Dharma Kabupaten Kubu Raya.

\section{Rata-Rata Skor Depresi Sebelum dan Sesudah Pemberian Terapi Progressive Muscle Relaxation (PMR) pada Kelompok Kontrol}

Sedangkan pada kelompok kontrol didapatkan rata-rata skor depresi sebelum pemberian terapi Progressive Muscle Relaxation (PMR) adalah 10,60. Karna kelompok kontrol tidak diberikan intervensi atau terapi Progressive Muscle Relaxation (PMR) sehingga rata-rata skor depresi mengalami peningkatan menjadi
11,15. Hal ini dapat disebabkan oleh berbagai faktor seperti usia, jenis kelamin dan status pernikahan lansia tersebut.

Pada hasil uji karakteristik responden pada kelompok kontrol didapatkan bahwa lansia elderly (usia 60-74 tahun) sebanyak 16 (80\%). Didasari oleh hasil penelitian yang dilakukan oleh Al-Khairi (2018) mengenai Determinan Tingkat Depresi pada Lansia di Panti Sosial Tresna Werdha Mulia Dharma bahwa depresi pada lansia prevalensinya tinggi dan semakin meningkat seiring bertambahnya umur lansia. Hasil mengenai tingkat depresi diperoleh bahwa ada sebanyak $38,9 \%$ lansia dengan usia 40-65 tahun mengalami depresi. Sedangkan lansia dengan usia 65 tahun keatas sebanyak $42,2 \%$ mengalami depresi.

Ternyata jenis kelamin juga menjadi salah satu faktor depresi pada lansia. Berdasarkan penelitian yang dilakukan oleh Sisi dan Ismahmudi (2020) mengenai Hubungan Usia dan Jenis Kelamin dengan Tingkat Depresi pada Lansia di Posyandu Lansia Wilayah Kerja Puskesmas Wonorejo Samarinda, dari 61 responden lebih banyak berjenis kelamin perempuan sebanyak 45 $(73,8 \%)$ responden, sedangkan berjenis kelamin laki-laki sebanyak $16(26,2 \%)$ responden. Menurut penelitian sebelumnya mengatakan bahwa depresi pada lansia lebih sering dialami pada perempuan, hal ini dikarenakan perempuan lebih sering melakukan pemeriksaan kesehatan sehingga depresi lebih sering terdeteksi. Selain itu juga ada kemungkinan perempuan cenderung terpapar dengan lingkungan stress dibanding pria. Salah satu penyebab depresi adalah akibat ketidakseimbangan hormon yang dialami perempuan menambah tingginya tingkat kejadian depresi perempuan (Nailil, 2013). Dari hasil karakteristik responden didapatkan bahwa pada kelompok kontrol didominasi oleh lansia perempuan sebanyak $13(65 \%)$ lansia.

\section{Pengaruh Terapi Progressive Muscle Relaxation (PMR) Terhadap Depresi Pada Lansia}

Berdasarkan hasil uji Paired Sampel T Test yang dilakukan pada kelompok intervensi didapatkan selisih dari rata-rata sebelum dan sesudah pemberian terapi Progressive Muscle Relaxation (PMR) sebesar 4,35 dengan nilai $\mathrm{p}=0,000(\mathrm{p}<0,05)$ yang berarti bahwa ada perbedaan yang bermakna terhadap skor depresi pada lansia sebelum dan sesudah pemberian terapi Progressive Muscle Relaxation (PMR). Pelaksanaan terapi Progressive Muscle Relaxation (PMR) yang didukung oleh antusiasme yang sangat baik dari responden menjadi pengaruh yang besar terhadap penurunan yang signifikan dari rata-rata skor depresi 
sebelum dan sesudah pemberian terapi. Responden melaksanakan terapi dengan baik dan sesuai dengan prosedur yang telah diberikan oleh peneliti, yaitu melakukan terapi dalam tiga sesi dan dilaksanakan sebanyak sekali setiap harinya yang berlangsung selama tujuh hari, terapi dilaksanakan selama 30-45 menit dalam sehari. Hal tersebut menunjukkan bahwa Progressive Muscle Relaxation (PMR) dapat mengurangi depresi yang dialami oleh lansia.

Progressive Muscle Relaxation (PMR) merupakan salah satu metode relaksasi sederhana yang melalui dua proses yaitu menegangkan dan merelaksasikan otot tubuh yang dapat memberikan perasaan rileks secara fisik. Penelitian yang dilakukan Rahmah (2017) mengenai Keefktifan Relaksasi Otot Progresif untuk Menurunkan Tingkat Depresi Lansia di Panti Jompo Tresna Werdha Mulia Dharma, yang diberikan selama 20-30 menit dalam sehari dan dilakukan selama seminggu secara teratur mampu menurunkan tangkat depresi yang dialami oleh lanisa di Panti Jompo tersebut dengan jumlah sampel sebanyak 28 responden. Progressive Muscle Relaxation (PMR) dapat memberikan pemijatan halus pada kelenjar tubuh, dapat menurunkan produksi kortisol dalam darah, serta dapat mengembalikan pengeluaran hormon yang secukupnya sehingga memberi keseimbangan emosi dan ketenangan pikiran (Diahputri, 2017).

Penelitian ini juga membuktikan penelitian yang dilakukan oleh Windarwati (2012) mengenai Pengaruh Terapi Relaksasi Otot Progresif Jenis Tension Relaxution Terhadap Penurunan Skor Depresi pada Lansia Di UPT Pelayanan Sosial Lanjut Usia Pandaan Kabupaten Pasuruan yang dilakukan pada 10 lansia didapatkan hasil bahwa adanya penurunan pada nilai mean skor depresi lansia, dimana diperoleh mean pretest sebesar 10,9 sedangkan mean posttest I dan 2 menurun menjadi 6,4 dan 5,7. Didapatkan nilai signifikansi $0,000(p<0,05)$, sehingga dapat diartikan bahwa terapi relaksasi otot progresif berpengaruh secara signifikan terhadap terjadinya penurunan skor depresi lansia di UPT Pelayanan Sosial Lanjut Usia Pandaan.

Hasil penelitian ini telah membuktikan bahwa Progressive Muscle Relaxation (PMR) dapat menurunkan skor depresi pada lansia di Panti Sosial Tresna Werdha (PSTW) Sabai Nan Aluih. Hal tersebut terbukti karena intervensi yang diberikan sesuai dengan penelitian Diahputri (2017), dimana Progressive Muscle Relaxation (PMR) diberikan selama 20-30 menit dalam sehari dan dilakukan selama seminggu secara teratur dapat menurunkan skor depresi pada lansia.

\section{SIMPULAN}

Karakteristik sampel dalam penelitian ini didominasi oleh kelompok lansia elderly (55\%) pada kelompok intervensi dan (80\%) pada kelompok kontrol, untuk jenis kelamin pada kelompok intervensi lebih banyak laki-laki (55\%) sedangkan pada kelompk kontrol lebih banyak perempuan (65\%), seluruh responden dalam penelitian ini sudah tidak memiliki pasangan, dan responden penelitian rata-rata tinggal dipanti $<5$ tahun. Terapi Progressive Muscle Relaxation (PMR) dapat menurunkan skor depresi pada lansia. Sebelum diberikan intervensi didapatkan rata-rata skor depresi pada lansia 10,45 menjadi 6,10 setelah diberikan terapi Progressive Muscle Relaxation (PMR). Adanya pengaruh Terapi Progressive Muscle Relaxation (PMR) untuk mengatasi depresi pada lansia.

\section{Saran}

Hasil penelitian ini menunjukkan bahwa terapi terapi Progressive Muscle Relaxation (PMR) pada lansia dapat merelaksasi tubuh dan fikiran lansia menjadi lebih releks dan tenang. Sehingga terapi ini dapat diaplikasikan sebagai salah satu terapi yang dapat dilakukan di Panti Sosial Tresna Werdha (PSTW). Hasil penelitian ini dapat dijadikan evidence based dalam membandingkan keefektifan berbagai terapi yang dapat diberikan pada lansia dengan masalah depresi. Perawat spesialis jiwa hendaknya menerapkan penggunaan terapi spesialis khususnya terapi Progressive Muscle Relaxation (PMR) dalam praktik mandiri keperawatan jiwa dan selalu mensosialisasikan kepada klien, keluarga, profesi lain dan masyarakat luas. Penelitian lebih lanjut dengan metode yang berbeda dapat dilakukan seperti metode kualitatif atau mix metode untuk melihat sejauh mana terapi Progressive Muscle Relaxation (PMR) dirasakan efektif dalam mengatasi masalah depresi pada lansia.

\section{DAFTAR PUSTAKA}

Al-Khairi, H. (2018). Determinan tingkat depresi pada lansia di Panti Sosial Tresna Werdha Mulia Dharma. Jurnal Mahasiswa PSPD FK Universitas Tanjungpura, 4(3).

Badan Pusat Statistik. (2019). Statistik penduduk lanjut usia 2019. Badan Pusat Statistik: Badan Pusat Statistik.

Badan Pusat Statistik. (2020). Statistik penduduk lanjut usia 2020. Badan Pusat Statistik: Badan Pusat Statistik.

Diahuputri, N. M. N. (2017). Efektivitas pemberian progressive muscle relaxation dibandingkan aromatherapy massage untuk meningkatkan kualitas tidur pada pekerja perempuan di Rumah Sakit Bali Royal Denpasar. Naskah Publikasi.

Muzamil, M. S., Afriwardi, A., \& Martini, R. D. (2014). Hubungan antara tingkat aktivitas fisik dengan fungsi kognitif pada usila di Kelurahan Jati Kecamatan Padang Timur. Jurnal Kesehatan Andalas, 3(2).

Nailil, M. (2013). Hubungan antara karakteristik dengan kejadian depresi pada lansia di panti werda pelkris pengayoman kota semarang. 
Rezky Pradessetia, Rika Sabri dan Dewi Eka Putri, Pengaruh Terapi Progressive Muscle Relaxation (PMR) terhadap Depresi Pada Lansia di Panti Sosial Tresna Werdha (PSTW) Sabai Nan Aluih Sicincin

Rahmah, S. A., dkk. (2017). Keefektifan relaksasi otot progresif untuk menurunkan tingkat depresi lansia di Panti Jompo Tresna Werdha Mulia Dharma. Jurnal Cerebellum, 3(November), 944-954.

Ratri, P. M. (2016). Penanganan depresi pada lansia di panti griya sehat bahagia karanganyar. Jurnal Cerebellum, 22(September), 233-348.

Sisi, N., \& Ismahmudi, R. (2020). Hubungan usia dan jenis kelamin dengan tingkat depresi pada lansia di Posyandu Lansia Wilayah Kerja Puskesmas Wonorejo Samarinda. Borneo Student Research (BSR), 1(2), 895-900.

WHO. (2018). Mental health action plan 2012-2020. Geneva: World Health Organization

WHO. (2013). Mental health action plan 2012-2020. Geneva: World Health Organization

Windarwati, H. D., Ar, A. C. Q., \& Putri, G. N. (2012, April). Pengaruh terapi relaksasi otot progresif jenis tension relaxation terhadap penurunan skor depresi pada lansia Di UPT Pelayanan Sosial Lanjut Usia Pandaan Kabupaten Pasuruan. In Prosiding Seminar Nasional \& Internasional.

Widianingrum, S., \& Rachma, N. (2017). Gambaran Umum Karakteristik Lansia Dengan Depresi di Panti Wilayah Kota Semarang (Doctoral dissertation, Diponegoro University).

Wreksoatmodjo, B. R. (2014). Beberapa kondisi fisik dan penyakit yang merupakan faktor risiko gangguan fungsi kognitif. Cermin Dunia Kedokteran, 41(1), 25-32. 